\title{
Silva Rupaine
}

\section{Emocionālās inteliǵgences nozīme sociālā darba izglìtībā}

\author{
doi:10.25143/soc-darbs_2021_ISBN-9789934563928_105-122
}

Sirds jeb tas, ko mūsdienās sauc emocionālā inteliǵgence, ir viedās gudrības avots.

Tikai ieklausoties otrā ar sirdi, apskatot vinu ar sirdsacìm, var cerēt vin,u saredzēt, sadzirdèt, patiesi izprast. ${ }^{1}$

Rudīte RAudupe

Kopsavilkums. Iepazīstinot ar emocionālās inteliǵences vietu sociālā darba izglīiībā Latvijā, vispirms vērība jāpievērš emocionālās inteliǵences koncepta attīstībai. Šajā publikācijā tiek atklāta emocionālās inteliǵences aktualitāte darba tirgū un sociālajā darbā, kā arì piedāvājumi mūsdienu neformālajā un akadēmiskajā izglìtỉbā, tostarp ir iekḷauti sociālā darba studentu viedokḷi par ieguvumiem Rỉgas Stradiṇa universitātē (turpmāk - RSU) ìstenotajā studiju kursā "Emocionālā inteliǵence sociālajā darbā" 2019. gadā.

Atslēgvārdi: emocionālā inteliğence, emocionālā izglìtotība, emocionālais kapitāls, sociālais darbs, sociālā darba izglìtība.

\section{Emocionālās inteligéences jēdziena skaidrojums}

Jēdziena "emocionālā inteliǵence" attīstības vēsture iesniedzas jau 20. gadsimta trīsdesmitajos gados, kad tika definēts jēdziens "sociālā inteliǵence" (Edward Thorndike, 1937), vēlāk tika radīts jēdziens "nekognitīvā inteliǵence" (David Wechsen, 20. gs. 40. gados) un "emocionālais spēks" (Abram Maslow, 20. gs. 50. gados). Jēdzienu "emocionālā inteliǵence" pirmoreiz 1964. gadā savā publikācijā "Jūtība pret emocionālām izpausmēm trīs saziṇas veidos" (Sensitivity to Emotional Expression in Three Modes of Communicating) lietoja Maikls Beldohs

\footnotetext{
${ }^{1}$ Raudupe, R. 2005. Labi l̦audis. Madris, 174.
} 
(Michael Beldoch). ${ }^{2}$ Jēdziena "emocionālā inteligence" pamatā ir amerikāṇu pedagoga un psihologa Hovarda Gārdnera (Howard Gardner, 1943) uzskats, ka neeksitē tikai viena tipa inteligence, bet gan ir vairāki tās veidi. Daudzveidīgo spēju modelī tiek izvirzīta valodnieciskā jeb lingvistiskā, logiski matemātiskā, vizuāli telpiskā, ķermeņa kustību, muzikālā, dabaszinātniskā un telpiskā, kā arī intrapersonālā un interpersonālā inteliğence (to dēvē arī par sociālo inteliğenci). Šie inteligences veidi tiek skaidroti kā spēju un prasmju kopums, ko var veidot un izkopt. ${ }^{3}$

Pagājušā gadsimta 90. gados šo jēdzienu lietoja un attīstīja daudzi autori Džons Maiers (John Mayer), Pìters Solovejs (Peter Solovey), Džons Gotmens (John Gottman), Rūvens Bārons (Reuven Bar-On), Klods Stainers (Claude Steiner) u. c.

Emocionālā inteligence ir cilvēka spēju kopums, kas ietver savu emociju un jūtu, un sava rakstura saprašanu, kas palīdz veiksmīgi veidot cilvēku savstarpējās emocionālās attiecības un līdz ar tām - visu savu dzìvi. ${ }^{4}$

Rūvens Bārons (Reuven Bar-On, 1997) piedāvāja emocionālās inteligéences jaukto modeli, kurā tā tiek definēta kā nekognitīvs spēju, kompetenču un prasmju kopums, kas ietekmē cilvēka spējas tikt galā ar apkārtējo apstākḷu prasībām un spiedienu. ${ }^{5}$

Savukārt emocionālās inteligéences jauktajā modelī, ko piedāvāja Dāniels Goulmens (Daniel Goleman), emocionālā inteliǵence ir definēta kā paškontroles, centỉbas, neatlaidības un spējas sevi motivēt kopums. ${ }^{6}$

Vēlāk šo jēdzienu attīstīja daudzi citi autori. Šìs publikācijas turpinājumā sociālā darba un izglītības kontekstā tiks pieminēti vien daži no viņiem.

Tonijs Morisons (Tony Morisson) izstrādāja emocionālās inteliǵgences paradigmu, kuras pamatā ir četri elementi - emociju pašapzināšanās, spēja apzināties citu cilvēku emocijas, pašmenedžments (savu emociju regulācija) un attiecību ar citiem cilvēkiem menedžments (sk. 1 . att.). ${ }^{7}$

\footnotetext{
${ }^{2}$ Afroz, A., Firoz, M., Pandey, V. K. 2017. Overview of emotional intelligence model measurement and development. International Research Journal of Commerce Arts and Science. 8(9), 132-144. https://www.academia.edu/34966270/OVERVIEW_OF_EMOTIONAL_ INTELLIGENCE_MODEL_MEASUREMENT_AND_DEVELOPMENT

${ }^{3}$ Geidžs, N. L., Berliners, D. C. 1998. Pedagog̛iskā psiholoǵija. Rīga: Zvaigzne ABC, 72.

${ }^{4}$ Gottman, J. 1997. Kinder brauchen emotionale Intelligenz. München, Zürich: Diana Verlag, 45.

${ }^{5}$ The Handbook of Emotional Intelligence: Theory, Development, Assessment and Application at Home, School, and in the Workplace. Bar-On, R., Parker, J. D. A., eds. San Francisco: Jossey-Bass, 2000, 20.

${ }^{6}$ Goulmens, D. 2001. Tava emocionālā inteligence. Rìga: Jumava, 13. lpp.

${ }^{7}$ Morrison, T. Emotional Intelligence, Emotion and Social Work: Context, Characteristics, Complications and Contribution. The British Journal of Social Work. 37(2), February 2007, 245-263. doi.org/10.1093/bjsw/bcl016
} 
S. Rupaine. Emocionālās inteligences nozīme sociālā darba izglīitībā

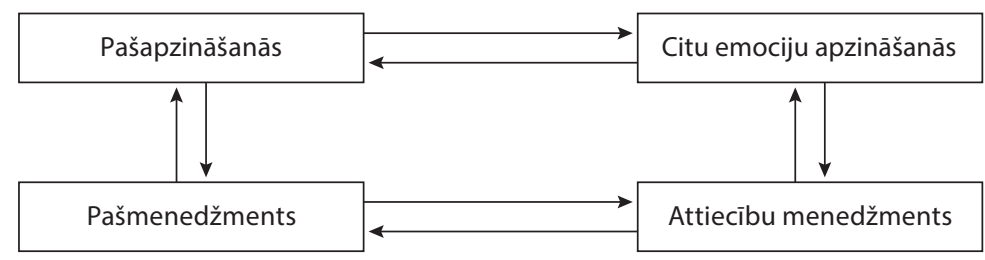

1. attēls. Emocionālās inteliǵences paradigma, ko izveidojis Tonijs Morisons

Aplūkojot emocionālās inteliğences paradigmu izglītības kontekstā, ir jāakcentē Stainera ieviestais jēdziens "emocionālā izglītotība jeb pratība" (angḷu val. emotional literacy), ko autors savos darbos aktualizēja jau 1979. gadā, vēl pirms jēdziena "emocionālā inteliǵence" ieviešanas (to radīja Solovejs un Maiers; ${ }^{8}$ Stainers emocionālo izglītotību jeb pratību definēja šādi:

“ [..] prasme, kas sevī ietver gan savu, gan citu emociju atpazǐšanu, kā arī prasmi zināt, kā vislabāk izpaust emocijas, lai sasniegtu maksimālu ètiskā, personīgā spēka pastiprinājumu". ${ }^{9}$

Stainers jēdzienam "emocionālā izglìtotība" jeb "emocionālā pratība" tuvo un līdzīgo jēdzienu "emocionālā inteliǵence" saskata kā saturiski identisku, atzīmējot to, ka jēdziens "emocionālā izglìtotība" jeb "pratība" tika radīts agrāk nekā jēdziens "emocionālā inteligenence", turklāt šis jēdziens ir daudz atpazīstamāks un populārāks. Autors uzskata, ka var trenēt emocionālās inteliǵences prasmes. Viņš izšķir piecas prasmes:

- prasmi atpazìt savas emocijas;

- empātijas prasmi - sajust citu cilvēku emocijas;

- prasmi vadit savas emocijas;

- prasmi vērst par labu, mainīt emocionālo kaitējumu;

- emocionālās interaktivitātes prasmi. ${ }^{10}$

Emocionālās izglìtības pamatā ir spēja saprast savas emocijas un to, kā emocijas produktīvi lietot. Emocionālā apzināšanās (angḷu val. awareness) nozīmē:

- zināt, ko jūtam;

- zināt, ko citi jūt;

- atrast emociju cēloṇus;

- zināt, kā mūsu emocijas var iespaidot citus. ${ }^{11}$

\footnotetext{
${ }^{8}$ Steiner, K. 1990. Achieving emotional literacy. London: Bloomsbury, 23-24.

9 Turpat, 219.

10 Turpat, 24-25.

11 Turpat, 30.
} 


\section{Emocionālās apzināšanās līmeni}

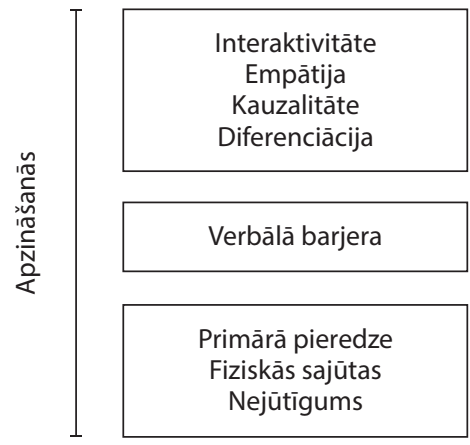

2. attēls. Emocionālās inteliǵences līmeṇi atbilstīgi Kloda Stainera iedalījumam

Raksta turpinājumā - īsumā par šiem līmeņiem (sk. 2. att.).

Atbilstīgi Kloda Stainera iedalījumam nejūtīgums ir viszemākais emocionālās apzināšanās līmenis. Šajā stāvoklī cilvēki neapzinās savas emocijas un jūtas. Tā var būt arī gadỉjumos, ja cilvēki ir stipru emociju varā.

Nākamo emocionālās apzināšanās līmeni ieņem stāvoklis, kuru Stainers nosauc par fiziskām sajūtām. Šajā līmenī tiek pieredzētas fiziskās sajūtas, kuras pavada emocijas, bet pašas emocijas netiek pieredzētas. Psihiatrijā lietotajā terminologijāa šādu stāvokli dēvē par somatizāciju.

Primārās pieredzes līmenī cilvēks apzinās emocijas, kuras pieredz kā visaugstākā līmeņa traucējošo enerğiju, kas netiek saprasta, un cilvēks to nespēj izteikt ar vārdiem. Tādējādi cilvēks savā emocionālajā stāvoklī ir viegli ievainojams un viņš reaǵē uz emocijām, taču nav spējīgs tās saprast un kontrolèt.

Verbālā jeb lingvistiskā barjera atdala iepriekš minētos emocionālās apzināšanās līmeņus no turpmākajiem. Lingvistiskās barjeras pārvarēšanai nepieciešama tāda apkārtējā vide, kas ir labvēlīga emocionālai informācijai. Tiklīdz šì barjera tiek šḳērsota, cilvēks ir spèjīgs runāt par savām emocijām, tādējādi arvien vairāk attīstot savu jūtu apzināšanās spēju.

Nākamais emocionālās apzināšanās līmenis tiek dēvēts par diferenciāciju, kas jau ir solis uz priekšu dažādu emociju atpazišanā un to intensitātes noteikšanā, kā arī runas prasmes apguvē - kā par savām emocijām runāt ar citiem. Šajā emocionālās apzināšanās stadijā cilvēki arvien vairāk apzinās atškirības starp pamatemocijām.

Kauzalitāte jeb cēlonība ir spēja izprast emociju cēloṇus - tas kḷūst iespējams, tiklīdz cilvēki apzinās emociju dabu. Šajā stadijā cilvēki apzinās emociju cēloṇus un notikumus, kas izraisa emocijas, piemēram, kāpēc tiek izjusts lepnums, naids vai bailes. 
S. Rupaine. Emocionālās inteligences nozīme sociālā darba izglìitībā

Empātija ir viena no augstākajām emocionālās apzināšanās pakāpēm. Tiklīdz cilvēks iemācās atškiirt dažādas emocijas un to intensitāti, kā arī iemeslus, kas tās rada, emociju apzināšanās kḷūst kvalitatīva un izsmalcināta, sākot uztvert un intuitīivi sajust līdzīgas emociju kvalitātes citos cilvēkos, kas ir līdzās. Empātija ir emociju intuīcijas forma.

Mijiedarbība jeb interaktivitāte ir visaugstākā emocionālās apzināšanās pakāpe. Emocionālā mijiedarbība ir vissarežgìtākais apzināšanās līmenis, tā ir spēja aptvert savas un citu jūtas un spēja paredzēt, kā emocijas mijiedarbosies. Tas nozīmē, ka var paredzēt, kā divi dažādi cilvēki, parādot savas parastās emocionālās tieksmes, reageēs konkrētajā situācijā.

Interaktivitāte empātiskiem cilvēkiem dod iespēju lietot emociju apzināšanos, lai virzītu emocionālās situācijas prasmīgā veidā. Interaktivitāte ir saikne starp emocionālo apzināšanos jeb apzinātību un emocionālo izglītotību. ${ }^{12}$

Viena no praktiskām emocionālās inteligences paradigmas sastāvdaḷām emociju pašapzināšanās instrumentiem - ir “emociju rats” (angḷu val. emotional wheel). Šo emociju apzināšanās instrumentu, proti, emociju ratu, ir radijis profesors Roberts Plučiks (Robert Plutchik), un tas var noderēt ne tikai sociālā darba studentiem, bet arī sociālā darba speciālistiem, strādājot ar klientiem. Emociju rats palīdz cilvēkiem vizualizēt emocijas un izprast emociju kombināciju - tas lauj izprast, kādas primārās un sekundārās emocijas tiek izjustas. Šis praktiskais vizuālais instruments vienkāršo emocijas, proti, klients var apskatīt "emociju rata" attēlu, kurā atainotas dažādas emocijas, un daudz precīāk noteikt tās, kuras viņš piedzìvo. Izpētot galvenās emocijas, var sākt apsvērt, kādi ir stimuli, kā tiek izteiktas emocijas un kādas darbības cilvēks veic šo emociju iespaidā. Izstrādājot savu notikumu shēmu, cilvēks var labāk apzināties savus ieradumus un uzvedību cēloṇu un seku sakarības savā dzīvē. Emociju apzināšanās arī dod iespēju dalīties ar jūtām, nevis tās apspiest vai ignorēt. ${ }^{13}$

Svarīgi ir izprast emocionālās apzināšanās nozīmību sociālajā darbā. Sociālo darbinieku rīcības pamatā ir palīdzošu attiecību veidošana ar cilvēkiem (klientiem), lai spētu rast visefektīvāko palīdzības veidu klientam. Attiecību būtība ir vairāk emocionāla nekā intelektuāla. Emocijas ir cilvēku visdziḷākā komunikācija ar apkārtējo pasauli - ar sevi un citiem. ${ }^{14}$

Attieksmju un emociju kontekstā spēja dalīties ar citiem un spēja ņemt ir primāri svarīgas, lai veidotu attiecības un tādējādi nodrošinātu iespējas paust

\footnotetext{
${ }^{12}$ Steiner, K. 1990. Achieving emotional literacy. London: Bloomsbury, 30.

${ }^{13}$ Karimova, H. Emotional Intelligence. The Emotion Wheel: What it is and how to use it. Positive Psychology. 04.07.2019. https://positivepsychology.com/emotion-wheel/

${ }^{14}$ Capaccione, L. 2006. The Art of Emotional Healing. Boston \& London: Shambala, 19.
} 
idejas un pieņemt lēmumus. Kad attiecībās ir jāpieredz jūtas vai attieksmes, kuras netiek atpazìtas vai ar kurām nevar vai nav vēlēšanās dalīties, attiecību avots aizsērē un vairs neveic savu divkāršo funkciju - atpazìt cilvēka emocionālās vajadzības un nodrošināt saikni, caur kuru var pieṇemt racionālus lēmumus. ${ }^{15}$

Tātad palīdzošu attiecỉbu priekšnoteikums ir emocionālās inteliǵences pilnveidošana - savu emociju atpazišana, prasme vadìt savas emocijas un pozitīvi ietekmēt otra cilvēka emocionālo stāvokli.

\section{Emocionālās inteliǵgences nozīme sociālajā darbā}

Sociālajā darbā emocionālās inteliǵences prasmes var lietot daudzkur. Tonijs Morisons, piemēram, norāda uz pieciem galvenajiem sociālā darba aspektiem, kuros svarīga vieta ir emocionālajai inteliǵencei:

- pakalpojumu piesaistī̌̌anā;

- novērtēšanā un novērošanā;

- lēmumu pieņemšanā;

- sadarbībā, kooperācijā un līdzdarbībā;

- stresa pārvarēšanā. ${ }^{16}$

Vērtējot emociju nozīmi sociālajā darbā, īpaši darba vides un profesionāḷu savstarpējās attiecībās, kā arī vadītāja darbā, tiek lietots jēeziens "emocionālais kapitāls", saturiski tajā iekḷaujot emocionālās inteligenences aspektus. Emocionālais kapitāls ir emocionālo kompetenču kopums, kas tiek attīstīts kopš agras bērnības lìdz pieaugušà vecumam gan neformālos veidos un kontekstos, gan sociālās vidēs gimenē, kaimiṇu attiecībās, vienaudžu un skolas, kā arī kopienas un sabiedrības kontekstā. Sociālā vide ir daudzveidīga - tā ietver grupas, pie kurām cilvēki pieder; vidi, kurā viṇi dzīvo un strādā; kā arī politiku, kas nosaka viṇu dzīvi, - tāpēc katram cilvēkam emocionālais kapitāls ir atšķirīgs. ${ }^{17}$

Emocionālā kapitāla līdzsvarošana ir pašattīstības, izaugsmes un mūžizglītības pamats, tā arī balsta spēju veiksmīgi un adekvāti sadarboties ar citiem.

${ }^{15}$ Brill, N. I. 1995. Working with People: The Helping Process. 5th ed. NewYork: Longman Publishers U.S.A., 98.

${ }^{16}$ Morrison, T. Emotional Intelligence, Emotion and Social Work: Context, Characteristics, Complications and Contribution. The British Journal of Social Work. 37(2), February 2007, 245-263. doi.org/10.1093/bjsw/bcl016

${ }^{17}$ Gendron, B. Emotional Capital: the set of emotional competencies as professional and vocational skills in emotional works and jobs. ResearchGate, May 2017. https://www. researchgate.net/publication/324794497_Emotional_capital_the_set_of_emotional_ competencies_as_professional_and_vocational_skills_in_emotional_works_and_jobs 
S. Rupaine. Emocionālās inteligences nozīme sociālā darba izglìitīāā

Emocionālā kapitāla līdzsvarošana cilvēkiem palīdz kḷūt izturīgiem, l̦aujot rast atbilstošus un produktīvus veidus, kā tikt galā ar stresu un vilšanos. ${ }^{18}$

Emocionālais kapitāls ir cilvēciskā kapitāla daḷa, un tas ir vienīgais kapitāls, kurā cilvēkiem, institūcijām un sabiedrībai vajadzētu ieguldìt, lai gūtu ekonomisko, sociālo un personīgo labumu:

- mikrolīmenī - cilvēka attīstībai mūžizglìtības perspektīvā, kas var radīt mazāku individuālismu un lielāku cilvēcisko iesaistī̌̌anos, izglìtības un darba vērtības respektēšanu ekonomiskajā un sociālā dzīvē (skolā, darbā);

- makrolīmenī - līdzdalībai sociālajā kohēzijā (lai visi reǵioni vienlīdzīgā apjomā varētu izmantot vienotā tirgus dinamisma priekšrocības) un pilsoṇu atbildībā, kas emocionālo kapitālu veido kā īstu un efektīvu personīgo, profesionālo, sociālo un organizācijas vērtību. ${ }^{19}$

Mūsdienu pasaulē jebkuram vadītājam un uzṇēmējam, tostarp arī sociālā darba institūcijas vadītājam, ir jābūt radošam, lai veidotu nevis vienkārši pakalpojumu, bet gan - labāko pakalpojumu. Un tas ir gandrīz neiespējami bez spējas pārvaldīt savas emocijas. ${ }^{20}$

Sociālā darba institūciju vadǐšanā un sociālo pakalpojumu sniegšanā svarīgi ir vērst uzmanību uz darba tirgus tendencēm, apzināt tās prasmes, kuras ir vitāli nepieciešamas mūsdienu darba tirgū, tādēl, izglìtojot nākotnes sociālā darba speciālistus, ir jāidentificē un jāpilnveido šìs prasmes. Lìdz ar to ir ḷoti svarīga emocionālās inteliğences izkopšana jau sociālā darba izglìtības ceḷā.

\section{Emocionālā inteligèence sociālā darba izglîtîbā}

Mūsdienu pasaulē, īpaši profesionālu darbinieku un vadītāju mācībās, tiek uzsvērta emocionālās inteligénces nozīme darbinieku pien̦emšanā, uzn̦ēmumu vadīšanā un darbinieku savstarpējo attiecību uzlabošanā. Pasaules ekonomikas

${ }^{18}$ Gendron, B. Emotional Capital: the set of emotional competencies as professional and vocational skills in emotional works and jobs. ResearchGate, May 2017. https://www. researchgate.net/publication/324794497_Emotional_capital_the_set_of_emotional_ competencies_as_professional_and_vocational_skills_in_emotional_works_and_ jobs

${ }^{19}$ Cottingham, M. D. Theorizing emotional capital. Theory and Society. 45, September 2016, 451-470. doi: 10.1007/s11186-016-9278-7

${ }^{20}$ Fannin, K. The Power of Emotional Capital in Building Influence and Relationships. Intelivate. May 11, 2018. https://www.intelivate.com/team-strategy/emotional-capitalhow-to-build-critical-leadership-wealth 
forumā 2018. gadā nolasītajā Ziṇojumā par darba vietu nākotni (angḷu val. Future of Jobs) tika norādīts, ka līdz 2022. gadam būs ievērojami mainījušās prasmes, kas vajadzīgas lielākajai dal̦ai darbu. Tas nozīmē, ka līdz 2022. gadam darba ņēmējus skars izmaiņas vidēji 42 \% nepieciešamo darba iemaṇu rādītājos. Prognozes rāda, ka nākamajos gados pieaugs analītiskās domāšanas un aktīvās mācīšanās nepieciešamība, kā arī būs pieprasījums pēc dažādu veidu tehnologiskām kompetencēm. Tomēr jauno tehnologiju prasmes ir tikai daļa no nākotnē vajadzīgā, tikpat nozīmīgas ir arī "cilvēciskās" prasmes - radošums, oriǵinalitāte un iniciatīva, kritiskā domāšana, pārliecināšana un sarunāšanās māka, kā arī spēja pievērst uzmanību detaḷām, noturība, elastība un sarežgìtu problēmu risināšanas iemaņas. Šajā ziṇojumā arī emocionālā inteliggence ir iekḷauta 10 pieprasītāko nākotnes prasmju sarakstā. ${ }^{21}$

Latvijas darba tirgu, kā arī sociālās politikas nozari regulē ilgtspējīgas attīstības stratēgija līdz 2030. gadam (Latvija 2030), kas ir galvenais valsts ilgtermina attīstības plānošanas dokuments. ${ }^{22}$ Šajā dokumentā ir noteikti vairāki būtiski aspekti tieši attiecībā uz emocionālo inteligenci, tostarp ietverti arī šādi pamatuzstādījumi - laimīgs cilvēks labklājīgā valstī; ilgtspējīgs un veselīgs dzīvesveids; radoša, iecietīga un toleranta sabiedrība; sadarbībā radīta konkurētspēja -, kas ir sasniedzami arī ar emocionālās inteligences attīstǐšanas un pilnveidošanas palīdzību. Latvijas Nacionālajā attīstības plānā 2014.-2020. gadam, kas ir dokumenta Latvija 2030 ìstenošanas plāns šim laikposmam, kā viena no prioritātēm minēta "cilvēka drošumspēja", kas ietver tādu emocionālās inteligenences komponentu kā adaptācijas spēju strauji mainīgā vidē - par sevi drošs, radošs cilvēks ir spējīgs parūpēties par sevi un citiem un pielāgoties apstākḷiem. ${ }^{23}$

Emocionālā inteligenence izglīiības un medicīnas nozarē Latvijā ir diezgan maz pētīta, taču daži pētijumi ir, piemēram, Rìgas Stradiṇa universitātē 2012. gadā tika veikts pētỉjums "Praktizējošo māsu personību raksturojošie faktori un profesionāli relevantā uzvedība”, kurā secināts, ka medmāsu emocionālā intelekta rādītāji ir visai augsti. ${ }^{24}$

${ }^{21}$ Ratcheva, V.S. 5 things to know about the future of jobs. World Economic Forum. September 17, 2018. https://www.weforum.org/agenda/2018/09/future-of-jobs-2018-things-to-know/

${ }^{22}$ Latvijas ilgtspèjīgas attīstības stratēgija līdz 2030. gadam. Pārresoru koordinācijas centrs. 2010. https://www.pkc.gov.lv/sites/default/files/inline-files/Latvija_2030_7.pdf

${ }^{23}$ Latvijas Nacionālais attīstības plāns 2014.-2020. gadam. Pārresoru koordinācijas centrs. 2012. https://www.pkc.gov.lv/sites/default/files/inline-files/20121220_NAP2020\%20 apstiprinats\%20Saeima_4.pdf

${ }^{24}$ Deklava, L. 2012. Praktizējošo māsu personību raksturojošie faktori un profesionāli relevantā uzvedība: promocijas darbs. Rīga: Rīgas Stradiṇa universitāte, 50. lpp. https://www.rsu.lv/ sites/default/files/dissertations/LDeklava_Promocijas_darba_kopsavilkums.pdf 
S. Rupaine. Emocionālās inteligences nozīme sociālā darba izglìitīāā

Savukārt Latvijas Universitātes (turpmāk - LU) 2009. gadā veiktajā pētijumā "Emocionālās inteliǵences loma sociālā darbinieka darbībā" tika konstatēts, ka sociālā darba studentiem ir vidēja līmeņa emocionālā inteligence, t. i., sociālie darbinieki apzinās savas emocijas, bet ne vienmēr zina, ko ar tām darìt. Reizēm viņi ir spèjīgi saprast jūtas un būt empātiski, bet reizēm var palikt vienaldzīgi pret citu cilvēku izjūtām. Sociālajiem darbiniekiem ar vidēju emocionālās inteliǵences līmeni nepieciešams pilnveidot emocionālās apzināšanās līmeni, lai spētu sniegt emocionāli inteligentu profesionālo palīdzību klientiem. ${ }^{25}$

Savukārt Rīgas Stradiṇa universitātē 2020. gadā veiktajā pētījumā "Sociālo darbinieku emocionālās intelig̉ences līmenis” tika secināts, ka sociālajiem darbiniekiem un sociālā darba studentiem emocionālās inteliǵgences līmenis ir drīzāk augsts, t. i., salīdzinot ar iepriekš minētā 2009. gada pētijuma datiem, tas ir augstāks. ${ }^{26}$

Grāmatas Emocionāli inteliǵents sociālais darbinieks autors Deivids Havs (David Howe) uzskata, ka sociālā darbinieka emocionālajai inteliǵencei ir jābūt visaugstākajā līmenī. ${ }^{27}$

Emocionālās intelig̣ences nozīmīgums ir neapšaubāms, tādēl emocionālās inteliǵgences prasmju pilnveidošanas jautājumiem ir būtiska vieta sociālā darba studentu un sociālo darbinieku neformālajā un akadēmiskajā izglìtībā.

Emocionālās inteliǵences pilnveide neformālās izglītības veidā tiek piedāvāta dažādos kursos gan biznesa pārstāvjiem un vadītājiem, gan arī plašai sabiedrībai. Piemēram, Latvijā kopš 2010. gada Latvijas Intelektuālās attīstības fonds sadarbībā ar Kalifornijas Universitāti Bērklijā organizē emocionālās inteliğences mācības. Kursus un seminārus, kuros ietverti emocionālās inteliǵences temati, regulāri piedāvā Lutera draudze un 2019. gadā tās paspārnē izveidotais Centrs cilvēka izaugsmei “Torṇakalns”, kura mērķis ir palīdzēt cilvēkiem apgūt emocionālās, intelektuālās, ķermeniskās un garīgās inteligenences attīstības daudzveidìgo praksi. ${ }^{28}$

L,oti nozīmīga ir emocionālās inteliǵences moduḷa, kā viena no trim modulịem (kopā ar garīgās un mentālās inteliğences moduḷiem), iekḷaušana Integrālās izglìtỉbas institūta mācību programmā.

${ }^{25}$ Poiša, S. 2009. Emocionālās inteliǵgences loma sociālā darbinieka darbībā: mağistra darbs. Rīga: Latvijas Universitāte.

${ }^{26}$ Fjodorova, M. 2020. Sociālo darbinieku emocionālās izglītības lìmenis: bakalaura darbs. Rīga: Rīgas Stradiṇa universitāte, 48.

${ }^{27}$ Howe, D. 2007. The Emotionally Intelligent Social Worker. Globe Press, 208.

${ }^{28}$ Centrs cilvēka izaugsmei “Torņakalns” ir atklāts. Rīgas Lutera draudze. http://luteradraudze.lv/blog/aktualitates/centrs-cilveka-izaugsmei-tornakalns-ir-atklats/ 
S. Rupaine. Emocionālās inteliǵences nozīme sociālā darba izglìtībā

Garīdznieks Juris Rubenis norāda:

"Cilvēks nav tikai racionāla būtne - patiesībā mūsu dzīves lielāko daḷu vada tieši emocionālie procesi. Ja cilvēkam trūkst emocionālās regulācijas prasmju, viṇš nespēj tikt galā ar savām emocijām, līdz ar to nodara pāri citiem un sev." ${ }^{29}$

Arī sociālā darba nozarē tiek piedāvāti emocionālās inteligences mācību kursi, taču tie nav regulāri, piemēram, 2014. gadā Labklājības ministrijas organizētajā vasaras skolā sociālajiem darbiniekiem viena no darbnīcām bija "Emocionālā inteligence", savukārt 2019. gada sākumā Latvijas Pašvaldību mācību centrs bāriṇtiesu darbiniekiem piedāvāja kursus "Emocionālā inteliğence saskarsmē un konfliktu risināšanā”.

Nozīmīga ir Sokrata tautskolas iniciatīva - ar mērḳi paaugstināt dzīves gudrības kompetenci kopš 2019. gada tā organizē mācību kursus sociālajiem darbiniekiem "Apzinātība sociālajā darbā". Šìs programmas trešais modulis "Emociju atpazīšana un stresi sociālajā darbā" satur tieši emocionālās inteligences jautājumus. ${ }^{30}$

Latvijas Universitātes (LU) pētījumā 2009. gadā Silva Poiša ${ }^{31}$ uzsvēra emocionālās inteliǵences līmeņa pilnveidošanas nozìmi augstākajā izglītībā, tostarp sociālā darba studentu emocionālās inteligences pilnveidošanas nepieciešamību:

"Jādod studentiem iespēja augt un pilnveidot arī emocionālo inteliǵenci, akcentējot to, ka studiju procesā jānokārto ieskaite par savām emocionālās inteliǵgences kompetencēm profesionālajā darbībā. Svarīgi, ka privātajā dzīvē cilvēks var izvēlēties darīt to, ko vēlas, taču profesionālajā jomā ir jāatpazīst savas emocijas un jāspēj tās menedžèt - būtiska ir emocionālās inteliǵences pilnveidošana augstskolā, lai efektīvāk sociālie darbinieki veidotu attiecības ar klientiem un risinātu sociālās problēmas." 32

Akadēmiskajā sociālā darba izglīiībā studiju kurss "Emocionālā inteligence sociālajā darbā” bija iekḷauts sociālā darba maǵistra programmā Vadības

${ }^{29}$ Četras prasmes dzīvei un darbam. Četru prasmju darbsemināra kurss vadītājiem. Integrālās izglìtības institūts. 23.10.2019. http://www.iii3.lv/instituts/jaunumi/231019. kurss-vaditajiem-cetras-prasmes-dzivei-un-darbam-/

${ }^{30}$ Izglītības programmas "Apzinātība sociālā darba praksē" 3. modulis "Stresu un emociju atpazī̌̌ana sociālajā darbā”. Sokrata tautskola. 06.12.2019. https://www.sokratatautskola. lv/events/izglitibas-programmas-apzinatiba-sociala-darba-prakse-3-modulis-stresu-unemociju-atpazisana-socialaja-darba/

${ }^{31}$ Silva Poiša, tagad Silva Rupaine.

${ }^{32}$ Poiša, S. 2009. Emocionālās inteliǵences loma sociālā darbinieka darbībā: maǵistra darbs. Rīga: Latvijas Universitāte, 61. 
S. Rupaine. Emocionālās inteligéences nozīme sociālā darba izglìīīā

un sociālā darba augstskolā "Attīstība". Taču tas tika îstenots vien dažus gadus, līdz augstskolas likvidācijai.

Emocionālā inteliǵence ir iekḷauta 10 pieprasītāko nākotnes prasmju sarakstā, un ir pierādīts, ka pastāv spēcīga saistība starp emocionālo inteliǵenci un akadēmiskajiem sasniegumiem. ${ }^{33}$ Tādēl, pateicoties Rìgas Stradiṇa universitātes asociētās profesores Lolitas Vilkas un Sociālā darba katedras darbinieku iniciatīvai, šāds kurss kopš 2019. gada tiek realizēts Rīgas Stradiṇa universitātes sociālā darba bakalaura studiju programmā.

Arī LU S. Poišas veiktajā pētījumā norādīts, ka bakalaura studiju programmas 3.-4. studiju gadā nepieciešams koncentrēties uz emocionālo izglītošanu:

"Pamatojoties uz teorētisko atziṇu, ka kognitīvais intelekts ir milzīga priekšrocība, ja tas ir apvienots ar emocionālo briedumu, - emocionālās inteligences un prāta apvienojums ir sociālā darbinieka efektīvas profesionālās darbības pamatā. [..] Ieteikums ir pārdomāt un izdiskutēt iespējas augstskolas ietvaros - pirmajos divos studiju gados - studiju kursu organizācijā un saturā vairāk koncentrēties uz topošo sociālo darbinieku prāta inteligéences [..] jeb kognitīvo izglìtošanu [... , veidojot sistematizēšanas, loğiskās spriestspējas prasmes, paralēli iekḷaujot arī emocionālo izglìtošanu, taču mazāk, un 3.-4. studiju gadā galvenokārt koncentrēties uz topošo un esošo sociālo darbinieku emocionālo izglîtošanu." ${ }^{34}$

N̦emot vērā šà pētỉjuma atziṇas, RSU studiju kurss "Emocionālā inteligence sociālajā darbā” iekḷauts sociālā darba izglìtības bakalaura programmas 4. studiju gadā.

Sociālā darba izglītība nebeidzas, kad iegūts sociālā darba profesionālais grāds. Tai jāturpinās mūžizglītībā. Sociālo pakalpojumu un sociālās palīdzības likumā noteikts, ka "pašvaldībai ir pienākums nodrošināt pašvaldības sociālā dienesta un citu pašvaldības izveidoto sociālo pakalpojumu sniedzēju sociālā darba speciālistiem profesionālās kompetences pilnveidi - apmācības un supervīziju”. ${ }^{35}$ N̦emot vērā šeit minēto, ir lıtoti būtiski pievērst uzmanību emocionālās inteliǵences pilnveidei.

${ }^{33}$ Jaeger, A. J. 2003. Job competencies and the curriculum: an inquiry into emotional intelligence in graduate professional education. Research in Higher Education. 44, 615-639. https://link.springer.com/article/10.1023/A:1026119724265

${ }^{34}$ Poiša, S. 2009. Emocionālās inteligences loma sociālā darbinieka darbībā: maǵistra darbs. Rìga: Latvijas Universitāte, 66.

${ }^{35}$ Sociālo pakalpojumu un sociālās palīdzības likums: Latvijas Republikas likums: pien̦emts 31.10.2002. un stājās spēkā 01.01.2003. Latvijas Vēstnesis. 168, 19.11.2002., 6. pants. https:// likumi.lv/ta/id/68488-socialo-pakalpojumu-un-socialas-palidzibas-likums/redakcijasdatums/2023/01/01 


\section{Emocionālās inteligences pilnveides cel̦i}

Emocionālo inteliğenci var pilnveidot mācoties. To apliecina daudzi pētījumi, piemēram, Odrija Džegera (Audrey J. Jaeger) uzskata, ka to var pilnveidot ar plānotu intervenci izglītības procesa rezultātā. ${ }^{36}$ Arī Rūvens Bārons pauž pārliecỉbu, ka emocionālā inteligence ir pilnveidojama. Pētỉjumi rāda, ka pēc speciāla treniņa pieaug emocionālās inteliğences rādītāji - empātija un emociju apzināšanās. ${ }^{37}$ Pētījumos secināts, ka sociālā darba studentiem ir nepieciešama emocionālās inteliǵences pilnveide.

LU veiktajā pētījumā (2009) tika izdalīi divi emocionālās inteliğences pilnveides ceḷi - profesionālais un individuālais. Profesionālajam ceḷam raksturīga akcentēta profesionālas supervīzijas un komunikācijas treniņu nozìme. ${ }^{38}$

2019.-2020. gadā RSU īstenotajā studiju kursā "Emocionālā inteliǵence sociālajā darbā” notika minilekcijas, pašrefleksija un emociju atpazišanas, regulācijas vingrinājumi (emociju kartes, emociju rats u. c.) un analìtiski uzdevumi, sociālā darbinieka un klienta intervences videomateriālu analīze, ètiskas sociālā darba situācijas, lomu spēles u. tml.

Otrs emocionālās inteliǵences ceḷ̌s jeb individuālais ceḷš tiek balstīts uz pašpieredzi un pašterapiju un tiek īstenots ar meditācijām, individuālu psihoterapiju, mākslas terapijas u. c. metodēm. ${ }^{39}$

Viena no emocionālās inteliǵences pilnveidošanas metodēm ir apzinātības meditācija, kura palīdz izpaust emocionālo inteliǵenci trīs galvenajos veidos:

1) uzlabo spēju izprast savas emocijas;

2) palīdz iemācìties atpazìt citu (apkārtējo) cilvēku emocijas;

3) stiprina spēju pārvaldīt un kontrolēt savas emocijas.

Cilvēkiem, kuri regulāri īsteno meditācijas praksi, ir augstāki emocionālās inteliğences rādītāji nekā tiem, kuri nemeditē. ${ }^{40}$

${ }^{36}$ Jaeger, A. J. 2003. Job competencies and the curriculum: an inquiry into emotional intelligence in graduate professional education. Research in Higher Education. 44, 615-639. https://link.springer.com/article/10.1023/A:1026119724265

${ }^{37}$ Gaitniece-Putāne, A. 2008. Agresijas, emocionālā intelekta un stoicisma saistība 20-25 un 30-35 gadus veciem respondentiem. No: Latvijas Universitātes Raksti. Rìga: Latvijas Universitāte, 742. sēj., 7.-28.

${ }^{38}$ Poiša, S. 2009. Emocionālās inteliǵences loma sociālā darbinieka darbībā: maǵistra darbs. Rìga: Latvijas Universitāte, 64.

39 Turpat.

${ }^{40}$ Charoensukmongkol, P. Benefits of Mindfulness Meditation on Emotional Intelligence, General Self-Efficacy, and Perceived Stress: Evidence from Thailand. Journal of Spirituality in Mental Health. 16, 2014, 171-192. doi: 10.1080/19349637.2014.925364 
S. Rupaine. Emocionālās inteligences nozīme sociālā darba izglìitīāā

Luīzes Grāntas (Louise Grant) pētījumi par palīdzošo profesiju pārstāvjiem sniedz atziṇu, ka apzinātības prasmes uzlabo daudzas citas prasmes, tostarp arī noturību, kas ir viena no drošumspējas formām: ${ }^{41}$ apzinātības prasmes uzlabo daudzas kompetences, kas ir noturības (spējas ātri atgūties pēc grūtībām un noguruma) pamatā, piemēram, refleksijas spēju, emocionālo inteliğenci un empātiju. Pētījumā tiek sniegti pierādījumi, ka palīdzošajiem speciālistiem apzinātība var mazināt nogurumu, kas rodas, izsakot līdzjūtību, kā arī mazināt profesionālo izdegšanu un emocionālās traumas, kuras var gūt, sniedzot palīdzìbu citiem. ${ }^{42}$

Rīgas Stradiṇa universitātes profesionālās sociālā darba studiju programmas studentiem jau pirmo trīs studiju gadu programmā tika piedāvātas dažādas pašizziņas un emocionālās kompetences attīstī̌šnas tehnikas, un viņi par šo apzinātības meditāciju izrādīja lielu interesi, tādēḷ nodarbībās tika pieaicināts vēl kāds pasniedzējs - viena meditācijas veida instruktors. Priecēja un pārsteidza studentu aktivitāte.

Ieskatu šajā emocionālās inteliǵences apzinātības apakštematikā studenti vērtēja šādi:

"Man ḷoti patika pieredze, jo pati vēlos sākt praktizēt meditāciju gan kustībā, gan mierā"; "visvairāk noderēja informācija, kā sevi kontrolēt dusmu un stresa brī̌̌os, kā rīkoties, lai sevi attīstītu kā cilvēku”; "[..] aizdomāties, cik svarīga tomēr ir mūsu domu un jūtu apzināšanās un saprašana un cik ḷoti tas palīdz ikdienas stresā, meditācija bija noderīga"; "[..] man emocionāli šis laiks bija diezgan grūts, tādēl šìs zināšanas nāca tieši laikā, jo tās sniedza atbildes uz jautājumiem, kas mani mocija".

Studentu vērtējums saskan ar Luīzes Grāntas pētījuma rezultātiem, kuri liecina, $\mathrm{ka}$

"[..] sociālā darba studentiem ir nepieciešams atbalsts, lai attīstītu viṇu empātiskās un refleksīvās prasmes, lai efektīvi pārvaldītu prakses emocionālās prasības. Par efektīviem atzīti tādi paņēmieni kā apzinātība un eksperimentālā mācišanās, refleksija". ${ }^{43}$

${ }^{41}$ NAP2020: Cilvēka drošumspēja un NAP2020. Pārresoru koordinācijas centrs. https:// www.pkc.gov.lv/lv/attistibas-planosana-latvija/nacionalais-attistibas-plans/nap2020

${ }^{42}$ Grant, L., Kinman, G. Emotional Resilience in the Helping Professions and how it can be Enhanced. Health and Social Care Education. 3(1), 2014, 23-24. https://www.tandfonline. com/doi/full/10.11120/hsce.2014.00040?src=recsys

${ }^{43}$ Grant, L. 2014. Hearts and Minds: Aspects of Empathy and Wellbeing in Social Work Students. Social Work Education. 33(3), 338-352. https://doi.org/10.1080/02615479.2013.80 5191 
Iepriekš minēto apliecina arī Silvas Poišas ieteikums LU veiktajā pētījumā:

"[..] paralēli visos studiju gados sociālā darba studentiem ieteicams papildus praktizēt pašterapiju un pašizziṇu”." ${ }^{44}$

Apzinātības meditācija tiek atzìta par vienu no efektīvākajām pašizziṇas un emocionālās inteligigences pilnveidošanas tehnikām. Apzinātība ir milzīgs izaicinājums un atbildība pašam pasniedzējam. Rakstu krājuma "Apzinātība un pieṇemšana sociālajā darbā” autori Felicija Marona (Felicia Marohn) un Sīdars Kūnss (Cedar Koons) apliecina, ka sociālajiem darbiniekiem apzināšanās prasme nākotnē būs vitāli svarīga:

“[..] paša sociālā darbinieka apzinātība (kurš to māca klientiem) ietekmē programmu efektivitāti (klientiem)". ${ }^{45}$

Sociālajiem darbiniekiem ir īpaši nozīmīgi pašiem lietot apzinātības praksi profesionālajā darbībā, tādējādi sniedzot sev atbalstu un uzlabojot labsajūtu, kā arī veicinot profesionālo izaugsmi. ${ }^{46}$

Daudzos pētijumos ir pierādīti ne tikai apzinātības meditācijas fiziologiskie, garīgie un emocionālās inteligences ieguvumi, bet arī tajos atklāta šīs metodes svarīgā loma sociālo darbinieku turpmākajā darbā un studentu ikdienā. Pasaulē ir daudzas universitātes, kurās apzinātības prakses tiek mācītas studentiem un pasniedzējiem, kā arī iekārtotas atbilstošas meditācijas telpas, piemēram, Kārnegija un Melona Universitātē (Carnegie Mellon University). ${ }^{47}$ Meditācijas metodes un pieejas universitātēs ir dažādas, piemēram, tiek praktizētas pat meditācijas kopā ar suṇiem..$^{48}$ N̦emot vērā studentu interesi un citu valstu pieredzi, domājams, vajadzētu izvērtēt apzinātības un meditācijas nepieciešamību RSU studentiem un pasniedzejjiem.

${ }^{44}$ Poiša, S. 2009. Emocionālās inteligenences loma sociālā darbinieka darbībā: maǵistra darbs. Rìga: Latvijas Universitāte, 66.

${ }^{45}$ Mindfullness \& acceptance in social work. Evidence-Based Interventions \& Emerging Applications. Ed. by Boone, M. S. Content Press, 2014, 72.

46 Turpat.

${ }^{47}$ Mindfulness room. Carnegie Mellon University. https://www.cmu.edu/wellness/ be-mindful/mindfulness/

${ }^{48}$ Donaldson, J. S. Mindfulness Meditation May Help Students Combat High Levels of Stress, Depression. NBC News. May 16, 2017. https://www.nbcnews.com/feature/collegegame-plan/mindfulness-meditation-may-help-students-combat-high-levels-stressdepression-n759971 
S. Rupaine. Emocionālās inteligences nozīme sociālā darba izglìitīāā

\section{Secinājumi}

Emocionālā inteligenence ir iekḷauta nākotnes pieprasītāko darba prasmju sarakstā.

Konstatēts, ka pašreiz sociālajiem darbiniekiem kopumā emocionālās inteliğences līmenis ir augstāks par vidējo, tāpēc sociālajiem darbiniekiem ir jātrenē emocionālās inteligences prasmes, pilnveidojot emocionālās apzināšanās līmeni, lai spētu sniegt emocionāli inteligentu profesionālo palīdzību klientiem.

Sociālā darba studentiem ir vajadzīgs atbalsts, lai attīstītu viņu emocionālās inteligences prasmes. Sociālā darba studentu emocionālā inteligenence jāpilnveido gan teorijas studijās, gan praksē, kā arī tās pilnveide jāiekḷauj sociālā darbinieka individuālajā savas personības attīstībā mūžizglìīibas procesā.

Studiju kursam "Emocionālā inteligence sociālajā darbā" ir otrreizēja piedzimšana pēc 10 gadiem, tas ir ieguvis jaunu elpu un atrodas pašā ceḷa sākumā ar cerību arī turpmāk saturiski daudz dziḷāk attīstīties un, līdz ar daudziem citiem studiju kursiem sociālā darba programmā, pilnveidot nākamajiem sociālajiem darbiniekiem augsti vērtēto un nepieciešamo emocionālās inteliǵences kompetenci.

\section{Importance of Emotional Intelligence in Social Work Education}

\section{Abstract}

This article provides an overview of the field of emotional intelligence in social work education in Latvia. The publication illustrates relevance of emotional intelligence in labour market and in the field of social work, including informal and academic social work education nowadays. Although emotional intelligence has been defined in many ways, this article focuses on the model of emotional literacy by Steiner C. (1997) and the concept of emotional capital by Gendron B. (2015) which are well acknowledged by educators, leaders in labour market and the workplace.

The opinions of social work students about the benefits of the study course "Emotional Intelligence in Social Work" implemented at Rīga Stradiņš University in 2019 are revealed. The results of the researches on the level of emotional intelligence of social workers in Latvia in 2009 and 2020 are included. The article 
discusses the importance of emotional intelligence for effective practice and the role of academic institutions and social work organisations in fostering development of emotional intelligence in social work students and practitioners.

Keywords: emotional intelligence, emotional literacy, emotional capital, social work, social work education.

\section{Avoti un literatūra}

1. Afroz, A., Firoz, M., Pandey, V. K. Overview of emotional intelligence model measurement and development. International Research Journal of Commerce Arts and Science. 8(9), 2017, 132-144. Iegūts no: https://www.academia.edu/34966270/OVERVIEW_OF_ EMOTIONAL_INTELLIGENCE_MODEL_MEASUREMENT_AND_DEVELOPMENT

2. Brill, N. I. 1995. Working with People: The Helping Process. 5th ed. NewYork: Longman Publishers U.S.A.

3. Capaccione, L. 2006. The Art of Emotional Healing. Boston \& London: Shambala.

4. Centrs cilvēka izaugsmei "Torṇakalns" ir atklāts. Rìgas Lutera draudze. Iegūts no: http:// luteradraudze.lv/blog/aktualitates/centrs-cilveka-izaugsmei-tornakalns-ir-atklats/

5. Charoensukmongkol, P. Benefits of Mindfulness Meditation on Emotional Intelligence, General Self-Efficacy, and Perceived Stress: Evidence from Thailand. Journal of Spirituality in Mental Health. 16, 2014, 171-192, doi:10.1080/19349637.2014.925364

6. Cottingham, M. D. Theorizing emotional capital. Theory and Society. 45, September 2016, 451-470, doi:10.1007/s11186-016-9278-7

7. Četras prasmes dzīvei un darbam. Četru prasmju darbsemināra kurss vadītājiem. Integrālās izglìtības institūts. 23.10.2019. Iegūts no: http://www.iii3.lv/instituts/ jaunumi/231019-kurss-vaditajiem-cetras-prasmes-dzivei-un-darbam-/

8. Deklava, L. 2012. Praktizējošo māsu personību raksturojošie faktori un profesionāli relevantā uzvedība: promocijas darbs. Rīga: Rīgas Stradiña universitāte. Iegūts no: https:// www.rsu.lv/sites/default/files/dissertations/LDeklava_Promocijas_darba_kopsavilkums. pdf

9. Donaldson, J. S. Mindfulness Meditation May Help Students Combat High Levels of Stress, Depression. NBC News. May 16, 2017. Iegūts no: https://www.nbcnews.com/ feature/college-game-plan/mindfulness-meditation-may-help-students-combat-highlevels-stress-depression-n759971

10. Fannin, K. The Power of Emotional Capital in Building Influence and Relationships. Intelivate. May 11, 2018. Iegūts no: https://www.intelivate.com/team-strategy/emotionalcapital-how-to-build-critical-leadership-wealth

11. Fjodorova, M. 2020. Sociālo darbinieku emocionālās izglìtības lìmenis: bakalaura darbs. Rìga: Rìgas Stradiṇa universitāte, 48.

12. Gaitniece-Putāne, A. 2008. Agresijas, emocionālā intelekta un stoicisma saistība 20-25 un 30-35 gadus veciem respondentiem. No: Latvijas Universitātes Raksti. 742. sēj. Rīga: Latvijas Universitāte.

13. Geidžs, N. L., Berliners, D. C. 1998. Pedagoǵiskā psiholoǵija. Rìga: Zvaigzne ABC. 
S. Rupaine. Emocionālās inteligéences nozīme sociālā darba izglìīīā

14. Gendron, B. Emotional Capital: the set of emotional competencies as proffessional and vocational skills in emotional works and jobs. ResearchGate, May 2017. Iegūts no: https:// WWW.researchgate.net/publication/324794497_Emotional_capital_the_set_of_emotional_competencies_as_professional_and_vocational_skills_in_emotional_works_ and_jobs

15. Gottman, J. 1997. Kinder brauchen emotionale Intelligenz. München, Zürich: Diana Verlag.

16. Goulmens, D. 2001. Tava emocionālā inteligence. Rīga: Jumava.

17. Grant, L. 2014. Hearts and Minds: Aspects of Empathy and Wellbeing in Social Work Students. Social Work Education. 33(3), 338-352. Iegūts no: https://doi.org/10.1080/0261 5479.2013.805191 Grant, L., Kinman, G. Emotional Resilience in the Helping Professions and how it can be Enhanced. Health and Social Care Education. 3(1), 2014, 23-24. Iegüts no: https://www.tandfonline.com/doi/full/10.11120/hsce.2014.00040?src=recsys

18. Howe, D. 2007. The Emotionally Intelligent Social Worker. Globe Press.

19. Izglītības programmas "Apzinātība sociālā darba praksê" 3. modulis "Stresu un emociju atpazī̌ana sociālajā darbā”. Sokrata tautskola. 06.12.2019. Iegūts no: https://www.sokratatautskola.lv/events/izglitibas-programmas-apzinatiba-sociala-darba-prakse-3-modulisstresu-un-emociju-atpazisana-socialaja-darba/

20. Jaeger, A. J. 2003. Job competencies and the curriculum: an inquiry into emotional intelligence in graduate professional education. Research in Higher Education. 44, 615-639. Iegūts no: https://link.springer.com/article/10.1023/A:1026119724265

21. Karimova, H. Emotional Intelligence. The Emotion Wheel: What it is and how to use it. Positive Psychology. 04.07.2019. Iegūts no: https://positivepsychology.com/emotionwheel/

22. Latvijas ilgtspējīgas attīstības stratēgija līdz 2030. gadam. Pārresoru koordinācijas centrs. 2010. Iegūts no: https://www.pkc.gov.lv/sites/default/files/inline-files/Latvija_2030_7.pdf

23. Latvijas Nacionālais attīstības plāns 2014.-2020. gadam. Pārresoru koordinācijas centrs. 2012. Iegūts no: https://www.pkc.gov.lv/sites/default/files/inline-files/20121220_ NAP2020\%20apstiprinats\%20Saeima_4.pdf

24. Mindfullness \& acceptance in social work. Evidence-Based Interventions \& Emerging Applications. Ed. by Boone, M. S. Content Press, 2014.

25. Mindfulness room. Carnegie Mellon University. Iegūts no: https://www.cmu.edu/wellness/ be-mindful/mindfulness/

26. Morrison, T. Emotional Intelligence, Emotion and Social Work: Context, Characteristics, Complications and Contribution. The British Journal of Social Work. 37(2), February 2007, 245-263. Iegūts no: doi.org/10.1093/bjsw/bcl016

27. NAP2020: Cilvēka drošumspēja un NAP2020. Pārresoru koordinācijas centrs. Iegūts no: https://www.pkc.gov.lv/lv/attistibas-planosana-latvija/nacionalais-attistibas-plans/ nap2020

28. Poiša, S. 2009. Emocionālās inteliǵgences loma sociālā darbinieka darbībāa: maǵistra darbs. Rīga: Latvijas Universitāte.

29. Raudupe, R. 2005. Labi ļaudis. Rīga: Madris.

30. Ratcheva, V. S. 5 things to know about the future of jobs. World Economic Forum. September 17, 2018. Iegūts no: https://www.weforum.org/agenda/2018/09/future-of-jobs2018-things-to-know/ 
S. Rupaine. Emocionālās inteliǵences nozīme sociālā darba izglītībā

31. Sociālo pakalpojumu un sociālās palīdzības likums: Latvijas Republikas likums: pieñemts 31.10.2002. un stājās spēkā 01.01.2003. Latvijas Vēstnesis. 168, 19.11.2002. Iegūts no: https://ikumi.lv/ta/id/68488-socialo-pakalpojumu-un-socialas-palidzibas-likums/ redakcijas-datums/2023/01/01

32. Steiner, K. 1990. Achieving emotional literacy. London: Bloomsbury.

33. The Handbook of Emotional Intelligence: Theory, Development, Assessment and Application at Home, School, and in the Workplace. Bar-On, R., Parker, J. A., eds. San Francisco: Jossey-Bass, 2000. 